\title{
HEREDITARY PHALANGEAL AGENESIS SHOWING DOMINANT MENDELIAN CHARACTERISTICS
}

\author{
BY \\ NESTA H. WELLS, M.B., Ch.B. \\ (Honorary Physician to the Duchess of York Hospital for Babies, Manchester) \\ AND .
MARGARET PLATT, M.B., Ch.B.
(Clinical Assistant)
}

A healthy baby, six months old, was brought to the Duchess of York Hospital, Manchester, in July, 1946, suffering from phimosis. It was noticed that his hands were deformed. His mother, formerly a nurse, was herself normal, but stated that the child's father and grandfather and several other relatives were similarly affected. She was, therefore, asked to collect further information, from which the accompanying genealogical tree was compiled.

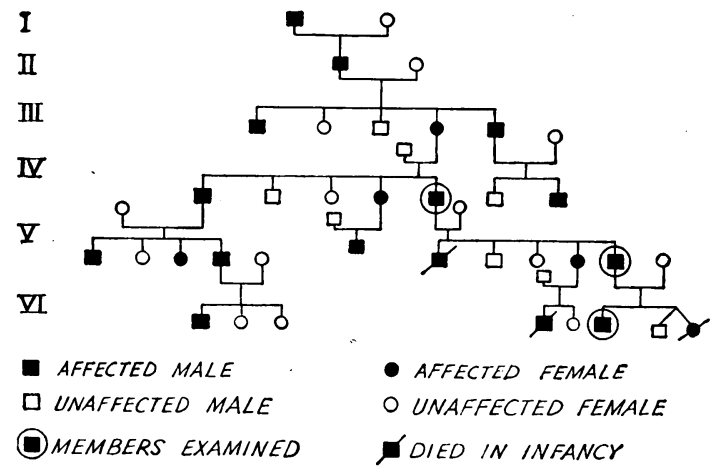

The deformity, an unusual one, was shown by radiograph to consist of absence of all the terminal phalanges of the fingers and also of the middle phalanges of the third and fourth fingers. In the first and second fingers the middle phalanges were rudimentary, and this was more marked in the right than in the left hand. The terminal phalanx of the left thumb was bifid, that on the right partially bifid.

The deformity of the fingers appears to be almost the same in all affected members of the family, the distal phalanges being absent and the middle phalanges either absent or rudimentary, but there is some variation in that of the thumb. For instance, the patient's right thumb is partially bifid like those of his grandfather, his left completely bifid like those of his father. There has been deformity of the toes in all the affected members except the patient's, where only a slight webbing is present.
The grandfather's foot deformity consists in absence of the distal phalanx of the third and fourth toes. It causes no difficulty in walking. Radiographs of the child's and the grandfather's hands and feet are shown (Plate VIII). The father, unfortunately, was unable to attend for x-ray examination, but has been examined by one of us (N. H. W.) and found to be similar to the grandfather with the exception of the thumbs which are splayed, suggesting the presence of a bifid terminal phalanx comparable to that in the child's left thumb.

In July, 1947, the mother again attended the out-patients' department, this time with a normal male child aged nine weeks. This child was the first-born of dissimilar twins and weighed $3 \mathrm{lb}$. at birth. The second twin, a girl weighing $4 \mathrm{lb} .10 \mathrm{oz}$., was reported to have shown the same phalangeal agenesis as the rest of the affected members of the family. Unhappily she died within two days of birth. We are indebted to the resident obstetric surgeon of St. Mary's Hospital, Manchester, for the following report on the female twin: "There was complete absence of the terminal phalanges of both hands with splaying of the thumbs. The toes were normal.' There is a history of twins in the mother's family, but none in the father's.

The mother was sure that no case had occurred in the children of unaffected members of the family. Their offspring are therefore not included, and no details are available of the siblings of the first and second generations. The offspring of some of the distant members of the family are not known, but, where given, they are complete.

It was stated that all the affected members were musical and had 'wonderful singing voices.' The family as a whole enjoyed music, but the affected members could 'sing and play easily and earn their living by it,' whereas the others could not. This statement was not confirmed for all the affected members, but in the immediate family of the child examined the great-grandfather was a church organist, and the grandfather was a singer on the variety stage. The father is by trade a cooper, but we are told he has an excellent singing voice. 
The condition has been handed down from parent to child for six generations. In the complete families of the third to the sixth generations there are thirty children, of whom eighteen are affected. Of the affected members, thirteen are males and five are females. In all the families but one, the first child is an affected male followed by an unaffected child, even in the twins.

The condition would therefore appear to be a heterozygous dominant. There have been no cousin marriages to illustrate the homozygous effect. The degree to which individual members are affected varies. In all but the patient and his sister, both hands and feet are deformed. In some the thumbs are merely flattened, in others definitely splayed.

No other deformity was discovered in the child, father, or grandfather examined. The family as a whole is reported to be healthy and many members have lived to over seventy.

\section{Discussion}

The mating of a dominant heterozygous individual with a recessive homozygote produces a back cross

generation of equal numbers similar to the parents. The expected ratio of unaffected to affected members would therefore be $1: 1$. In the case under discussion, it is twelve unaffected to eighteen affected, in the siblings of the complete families. Of the latter, thirteen are males and five females.

There is no evidence of complete sex linkage. The preponderance of males is not so great as at first appears, as the total number of males is high, being 19:11. The deformity is therefore carried by a dominant autosomal gene.

The marked musical capacity of the affected members suggests that there is a linkage between the gene producing the developmental defect and one influencing voice production and musical capability.

\section{Summary}

A description is given of an inherited deformity of the extremities showing a combination of ectrodactyly and polydactyly passing through six generations as a heterozygous dominant with some male preponderance. The gene appears to be linked with one producing musical capability.

(For illustrations to this article see Plate VIII, p. 260.) 


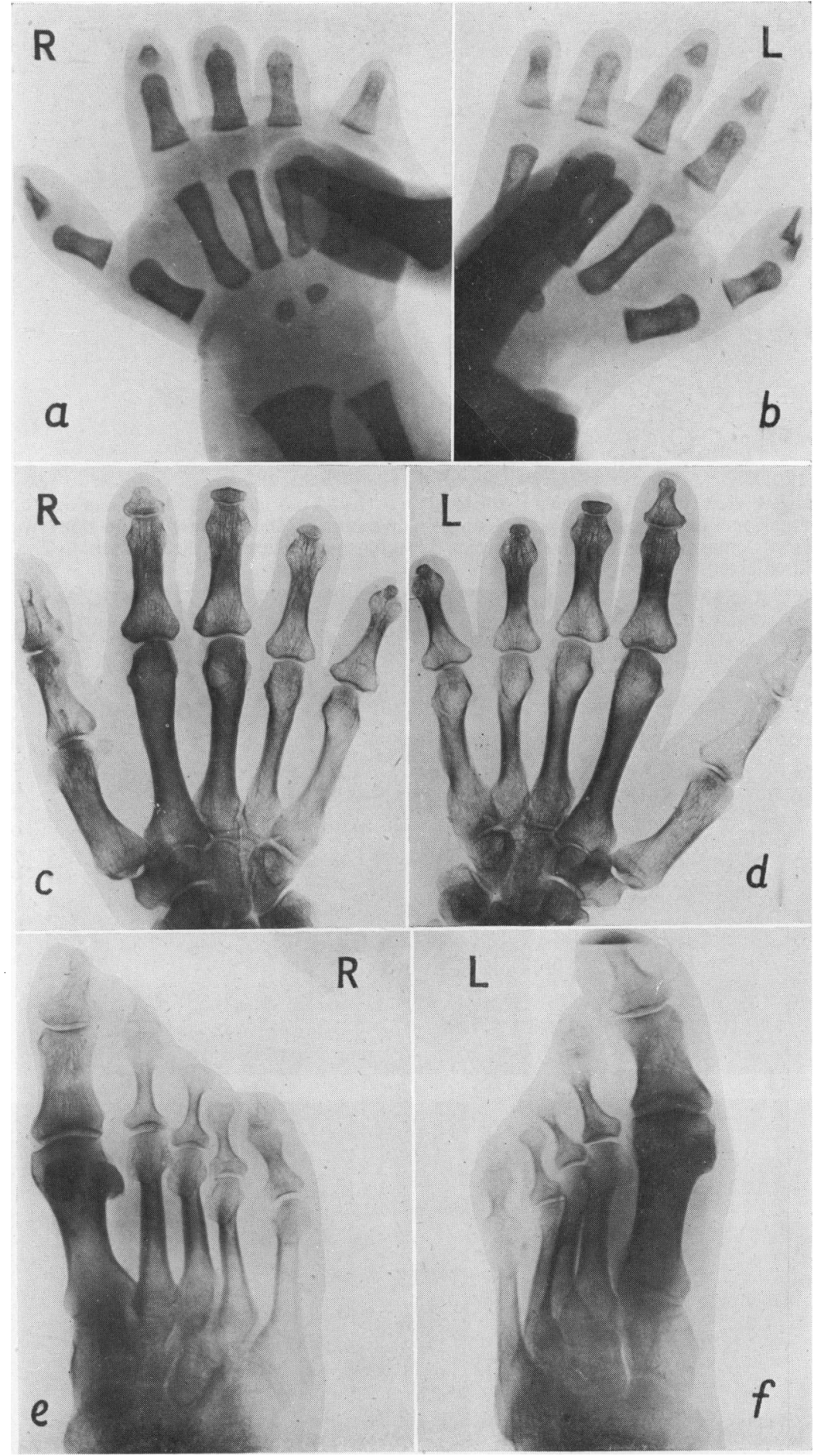

Shows (a) baby's right hand, (b) baby's left hand, (c) grandfather's right hand, (d) grandfather's left hand, (e) grandfather's right foot, and (f) grandfather's left foot. 